\title{
Influences Between Soil Microbiological and Agrochemical Parameters in an Organic Edible Rose Plantation
}

\author{
Ana Cornelia BUTCARU*, Cristian POMOHACI, Roxana MADJAR, Cosmin Alexandru MIHAI, Florin \\ STĂNICĂ \\ University of Agronomic Sciences and Veterinary Medicine of Bucharest, Romania \\ *corresponding author: anabutcaru@gmail.com \\ BulletinUASVM Horticulture 77(1) / 2020 \\ Print ISSN 1843-5254, Electronic ISSN 1843-5394 \\ DOI:10.15835/buasvmcn-hort: 2020.0005
}

\begin{abstract}
The aim of this study is to present the results of the organic technology applied to increase and maintain the biological soil activity in an organic edible rose plantation established within USAMV Bucharest. Before and after planting, three ameliorative species: Sinapis alba L., Phacelia tanacetifolia L. and Tagetes patula L. were sown in seven variants for increasing soil biological activity. Two types of mulches, woodchips and wool, were applied on the rose rows. The results presented statistically significant correlations between different microbiological and agrochemical parameters. A strong correlation between the fungi number and soil respiration $(r=0.94, p<0.05)$ was observed on the mulched rows. The soil bacteria number was positive correlated with humus content ( $\mathrm{r}=0.68$, $\mathrm{p}<0.05)$ and negative with mineral nitrogen $(\mathrm{r}=-0.66, \mathrm{p}<0.05)$. Positive correlation between soil respiration and assimilable potassium content $(r=0.83, p<0.05)$ was noticed, confirming its role in soil microorganism growth.
\end{abstract}

Keywords: ameliorative plants; edible Rosa sp; organic mulch; soil bacteria; soil fungi

\section{Introduction}

In organic orchards, soil biological activity and agrochemical parameters are important for the quality of products. Increasing soil microbiological parameters is one of the most important activities at the beginning and after the orchards establishment (Butcaru et al., 2017b; Butcaru et al., 2018; Butcaru et al., 2019). Many research studies have focused on soil bacteria and fungi importance in horticultural ecosystems. Aghaalikhani and Ehteshami (2008) mentioned their role in agroecosystem, being an important factor in reducing inputs as well. Pseudomonas $s p$. was used in hydrocarbon degradation
(Pacwa-Płociniczak et al., 2013); bio surfactants in agriculture for pesticide degradation were mentioned by Grebenişan (2007). The role of Trichoderma harzianum Rifai 1295-22 (T-22) in plant growth and pathogen biocontrol was mentioned by Norvell et al. (1999) and Velivelli et al. (2015).

Vegetative material derived from green fertilizers, respectively ameliorative plants, plays a role in reducing the pathogens in the soil and the diseases (Wang et al., 2009). Neață (2002) emphasized the role of soil microorganisms in the decomposition of organic substances and their participation in soil pedogenesis, contributing 
to the formation of humus. Bettiol et al. (2002) stated that microbial biomass is higher in organic than in conventional managed soil. Lipșa et al. (2008), studying the biological activity of the soil under different combinations of plant species, confirmed the higher percentage of soil bacteria compared with fungi. De Araújo and Melo (2010) mentioned that in organic farming the quantities of fertilizers are limited, the plants depending almost exclusively on the nutrient transformations in the soil. These are the result of the action of microorganisms, emphasizing their important role in the organic farming system.

Sinapis alba L. and Phacelia tanacetifolia L. are known to improve the soil structure and increase fertility, also as biomass plants in foraging activity of honey bees. Together with Tagetes patula $\mathrm{L}$. present anti-nematodes properties and weeds control, having allelopathy properties. Sinapis $a l b a$, in the form of seed flour, acts as an organic bio-herbicide; it is used in heavy metals recovery from contaminated soils; acts in phosphorus mobilization and availability; controls soil pathogens without affecting the microorganism involved in the nitrogen cycle. Tagetes patula $\mathrm{L}$. is involved in microclimate changes and used in disease and pest removal. (Berca, 2011; Bjorkman etal., 2011; De Baets etal., 2011; Dhima et al., 2010; Foucault et al., 2013; Fuks et al., 2013; Hooks et al., 2010; Hossain et al., 2015; ITAB and GRAB, 2011; Liu et al., 2013; Maltais-Landry, 2015; Ramirez et al., 2009; Robacer et al., 2015; Santos et al., 2015; Stănică and Peticilă, 2011; Wang et al., 2015).

The aim of this study is to present the correlations between microbiological and agrochemical soil parameters in an organic edible rose plantation, results of three ameliorative plants (Sinapis alba L., Phacelia tanacetifolia L. and Tagetes patula L.) and two mulch variants (woodchips and wool) used for increasing soil biological activity.

\section{Material and methods}

\section{Description of the study site}

In 2015, in the Experimental Field of Faculty of Horticulture within USAMV Bucharest, an organic edible rose plantation with three edible climbing varieties from David Austin collection as follows: Crown Princess Margareta, Falstaff and Brother Cadfael was established. Before and after planting, three ameliorative species: Sinapis alba L., Phacelia tanacetifolia L. and Tagetes patula L. were sown in seven variants for increasing the soil biological activity. After flowering the plants were mowed and after 14 days incorporated into the soil. Two types of mulches, woodchips and wool, were applied on the rose rows. Soil type was Tehnosol, Copertic subtype with a clay-sandy texture in 0-20 $\mathrm{cm}$ horizon, sandy-clay texture in $20-40 \mathrm{~cm}$ and low-alkaline $\mathrm{pH}$. Soil samples were taken at the beginning of the experiment and every year after using the ameliorative plants. Between 2015 and 2017, the average values of temperatures (daily minimum, maximum and medium) didn't differ statistically. The average minimum temperature varied between $-10^{\circ} \mathrm{C}$ and $-5^{\circ} \mathrm{C}$ and the average maximum temperature varied between $30^{\circ} \mathrm{C}$ $32^{\circ} \mathrm{C}$. The annual rainfall value varied from 688.20 $\mathrm{mm}$ (2015), $716.00 \mathrm{~mm} \mathrm{(2016)} \mathrm{to} 783.00 \mathrm{~mm}$ (2017), with the maximum values in November (2015) respectively October (2016 and 2017). The minimum rainfall values were registered in December $(2015,2016)$ and September (2017).

\section{Biological material and experimental variants}

Three climbing edible roses from David Austin collection (Crown Princess Margareta, Falstaff and Brother Cadfael grafted on Rosa laxa Retz) were planted. All the three ameliorative species used (Sinapis alba L., Phacelia tanacetifolia L. and Tagetes patula L.) were sown in 7 variants: V1 Sinapis, V2 Sinapis + Phacelia, V3 Phacelia, V4 Sinapis + Tagetes, V5 Sinapis + Tagetes + Phacelia, V6 Tagetes + Phacelia, V7 Tagetes and a control parcel V8, was kept as black field, without sowing. On the rose rows, the soil was mulched with wool and woodchips for each initial variant (Vn): Vn.1 woodchips and Vn.2 wool, while the control Vn.3, was represented by unmulched soil. Both mulched rows had the same $1 \mathrm{~m}$ width with the specific material (Fig. 1, 2 and 3).

\section{Experimental procedures for collecting data}

Microbiological (soil bacteria and fungi number and species, soil respiration) and agrochemical ( $\mathrm{N}, \mathrm{P}_{\mathrm{AL}}, \mathrm{K}_{\mathrm{AL}}, \mathrm{pH}$ and humus content) parameters analyses to monitor the soil activity were made at the beginning of the experiment and two years after, each autumn, after applying the technological phases (Butcaru et al., 2017; 2018; 2019). Microbiological analysis studied the number of heterotrophic bacteria determined using dilution plate method - by dispersing 


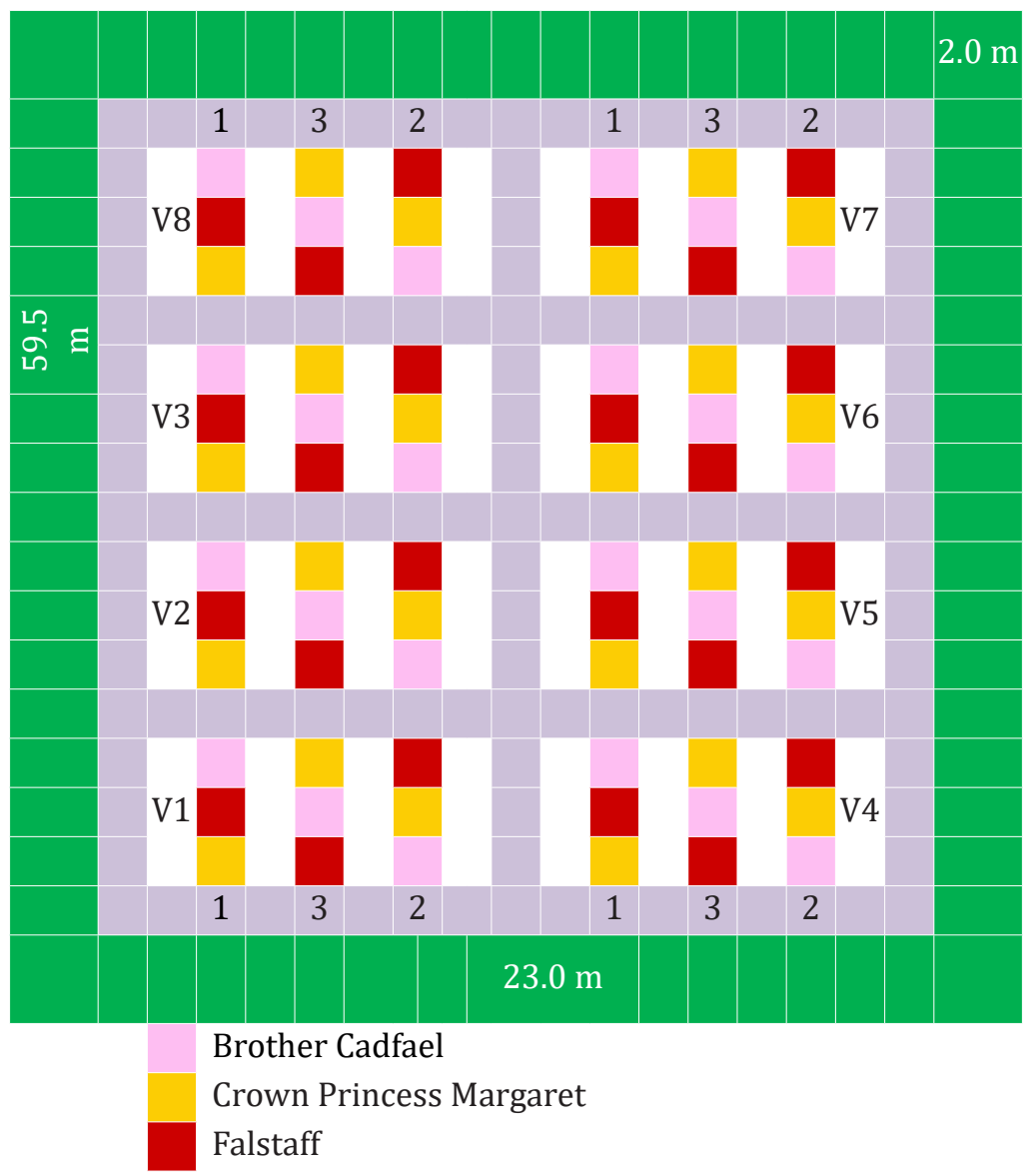

Figure 1. Experimental design (ameliorative plants, mulch and rose cultivars)

soil suspensions on the nutrient agar medium; number of microscopic fungi determined by dispersing soil suspension on PDA medium and soil respiration determined through the substrate induced respiration method according to RS-ISI-14240-1 (2012). The taxonomical identification was carried out on the basis of the cultural, morphological and/or physiological characteristics in accordance with bacteria Identification Manual (Bergey, 1994) and fungi in agricultural soils (Domsch and Gams, 1972). Agrochemical analysis determined the mineral N, mobile forms of $\mathrm{P}_{\mathrm{AL}}$ and $\mathrm{K}_{\mathrm{AL}}$, the amount of humus and soil $\mathrm{pH}$ on two horizons $0-20 \mathrm{~cm}$ and 20-40 $\mathrm{cm}$. Measurements were carried out according to the following methodologies: soil moisture by gravimetric method, $\mathrm{pH}$ by potentiometric method in aqueous suspension $(1: 2.5)$, mineral nitrogen as sum of ammonium and nitrate available in soil evaluated by spectrophotometry, mobile forms of $\mathrm{P}_{\mathrm{AL}}$ and $\mathrm{K}_{\mathrm{AL}}$ by Egner - Riehm - Domingo method, humus content was calculated from organic carbon determination with Walkley - Black - Gogoașă method (Madjar and Davidescu, 2004).

\section{Statistical analysis}

For the descriptive statistics of the data we used Microsoft Excel 2016, and for the inferential statistics (correlation, regression, etc.) we used GNU PSPP 1.0.1 v.2016 (the open source version of SPSS). The linear correlation was considered significant for a significance level $p=0.05$. Also, for each correlation, the coefficient of determination $\mathrm{r}^{2}$ was calculated.

\section{Results and discussions Soil microbiological parameters correlations}

On the woodchips rows, positive correlations between bacteria with fungi number $(\mathrm{r}=0.66, \mathrm{p} £ 0.05)$, bacteria with soil respiration $(\mathrm{r}=0.72, \mathrm{p}<0.05)$, fungi with soil respiration $(r=0.94, p<0.05)$ were registered (Fig. 4). 

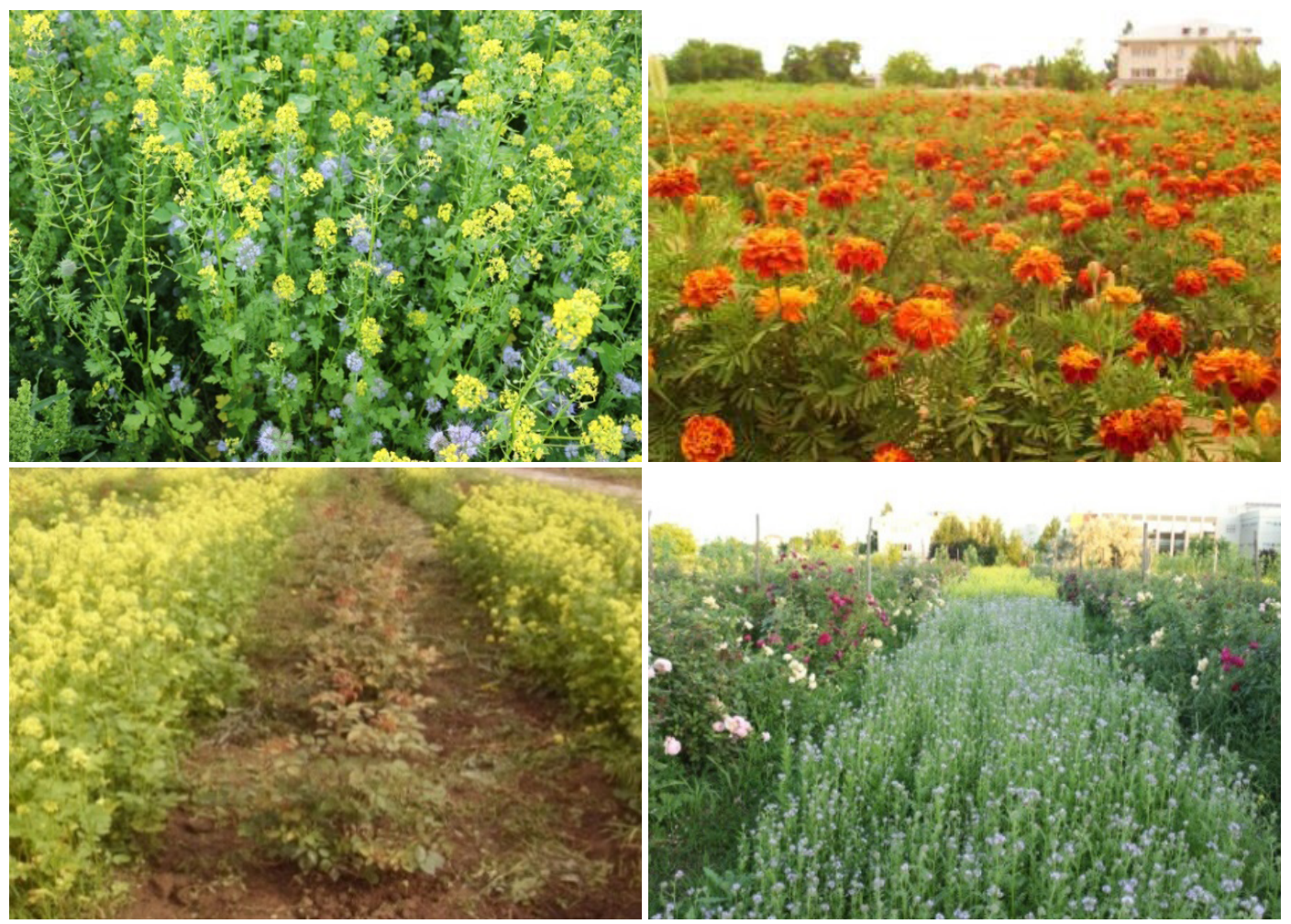

Figure 2. Sinapis alba, Phacelia tanacetifolia and Tagetes patula blooming

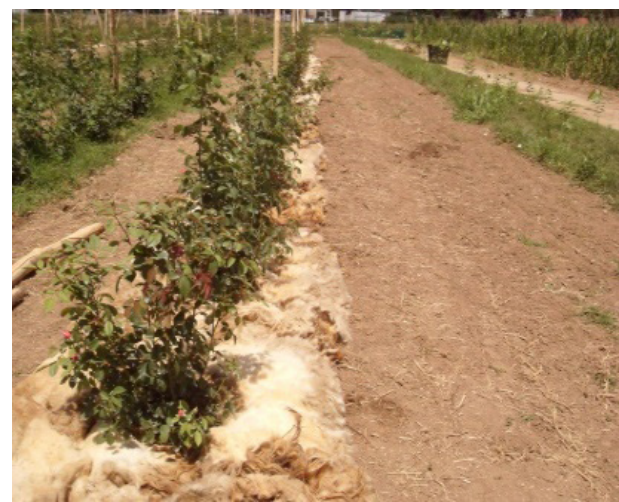

a

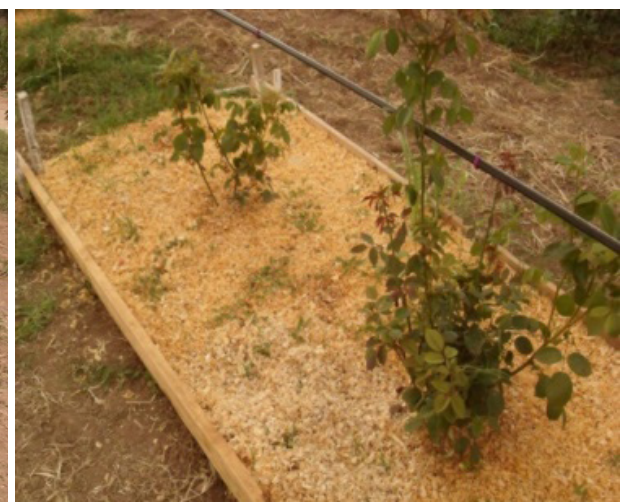

b

Figure 3. Mulch variants: wool (a) and woodchips (b)

In wool mulched rows, positive correlations between fungi with soil respiration $(r=0.94$, $\mathrm{p}<0.05$ ) and bacteria number with soil respiration $(r=0.68, p<0.5)$ were maintained (Fig. 5).

In the unmulched rows, positive correlations between fungi with soil respiration $(r=0.77$, $\mathrm{p}<0.05$ ) and bacteria number with soil respiration $(\mathrm{r}=0.75, \mathrm{p}<0.05)$ were also noticed (Fig. 6).

Soil respiration parameter is a result of soil microorganism existence and activity (Muller, 1965; Ștefanic et al., 2006). On the mulched rows, stronger correlations between fungi number with soil respiration comparative with the unmulched rows were noticed, due to specific organic material. The regression coefficients are bigger in the correlation of fungi than of bacteria with soil respiration. Flaviobacterium sp. and Pseudomonas sp., identified in the soil bacteria, Gram-negative bacteria, could be a possible cause of positive correlation between fungi and bacteria number, besides their multiplication due to organic mulch (Ștefanic et al., 2006). 


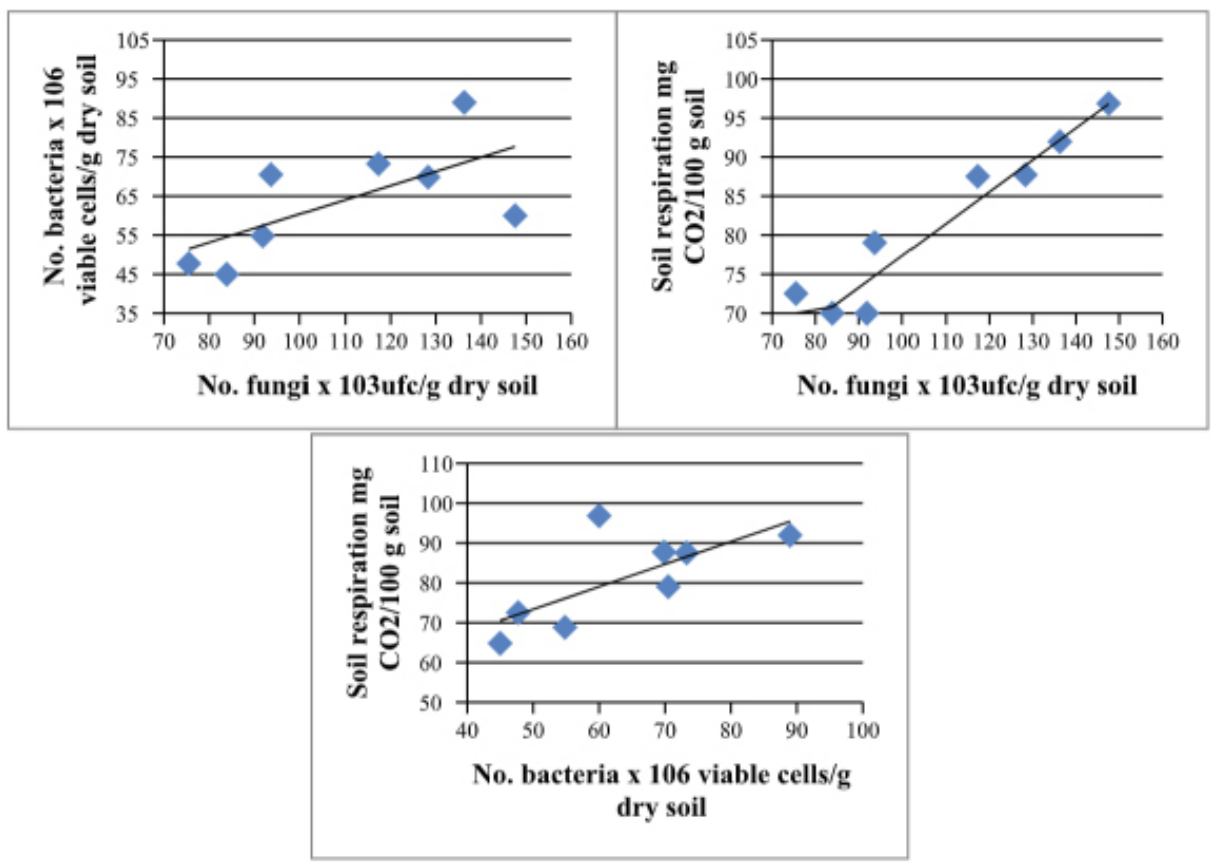

Figure 4. Correlations between soil microbiological parameters in woodchips variants

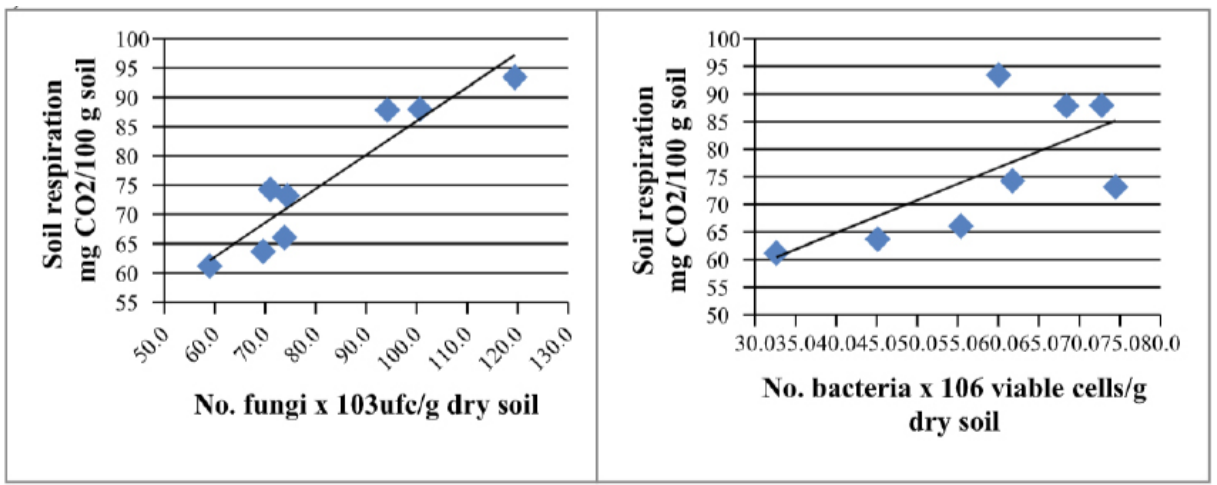

Figure 5. Correlations between microbiological parameters in wool variants

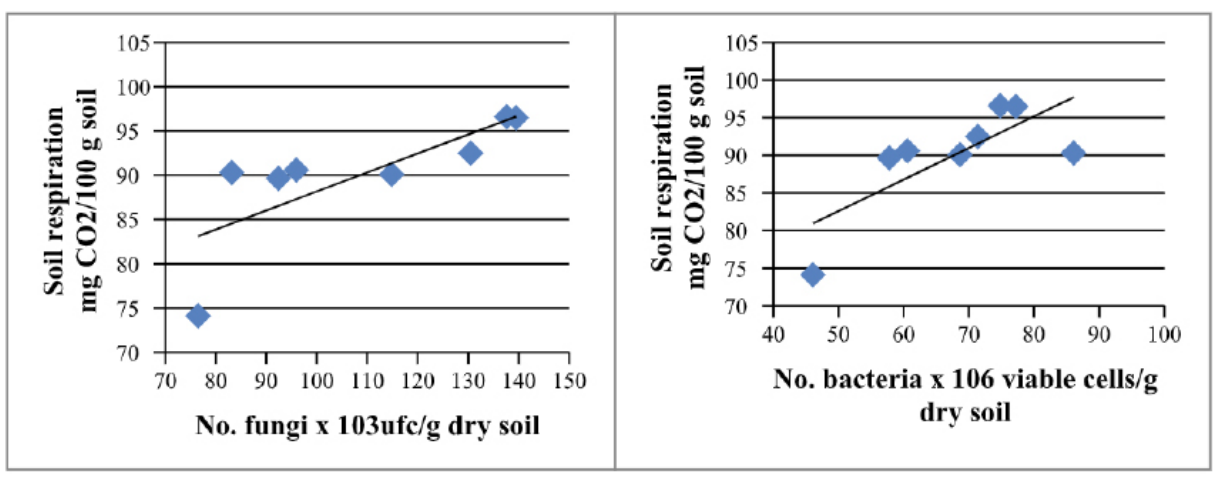

Figure 6. Correlations between microbiological parameters in un-mulched variants 


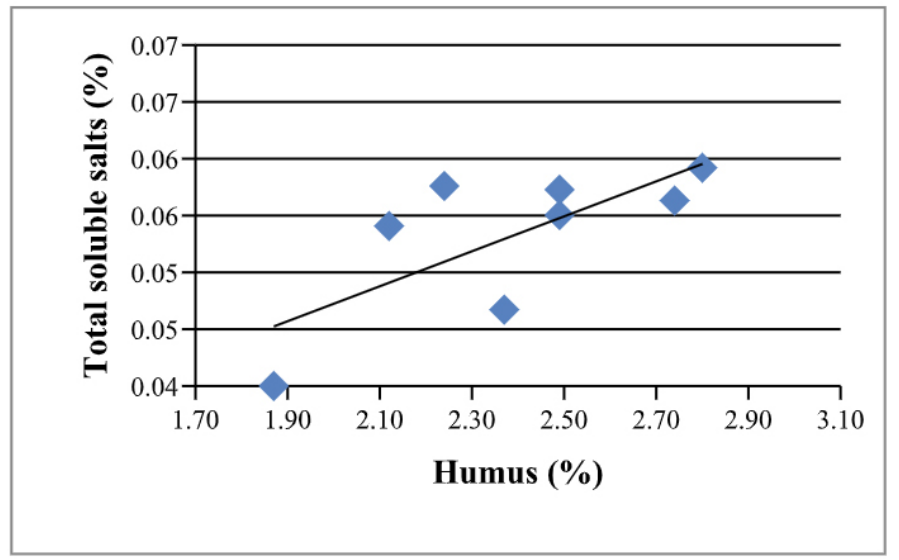

Figure 7. Correlation between soil humus and TSS content

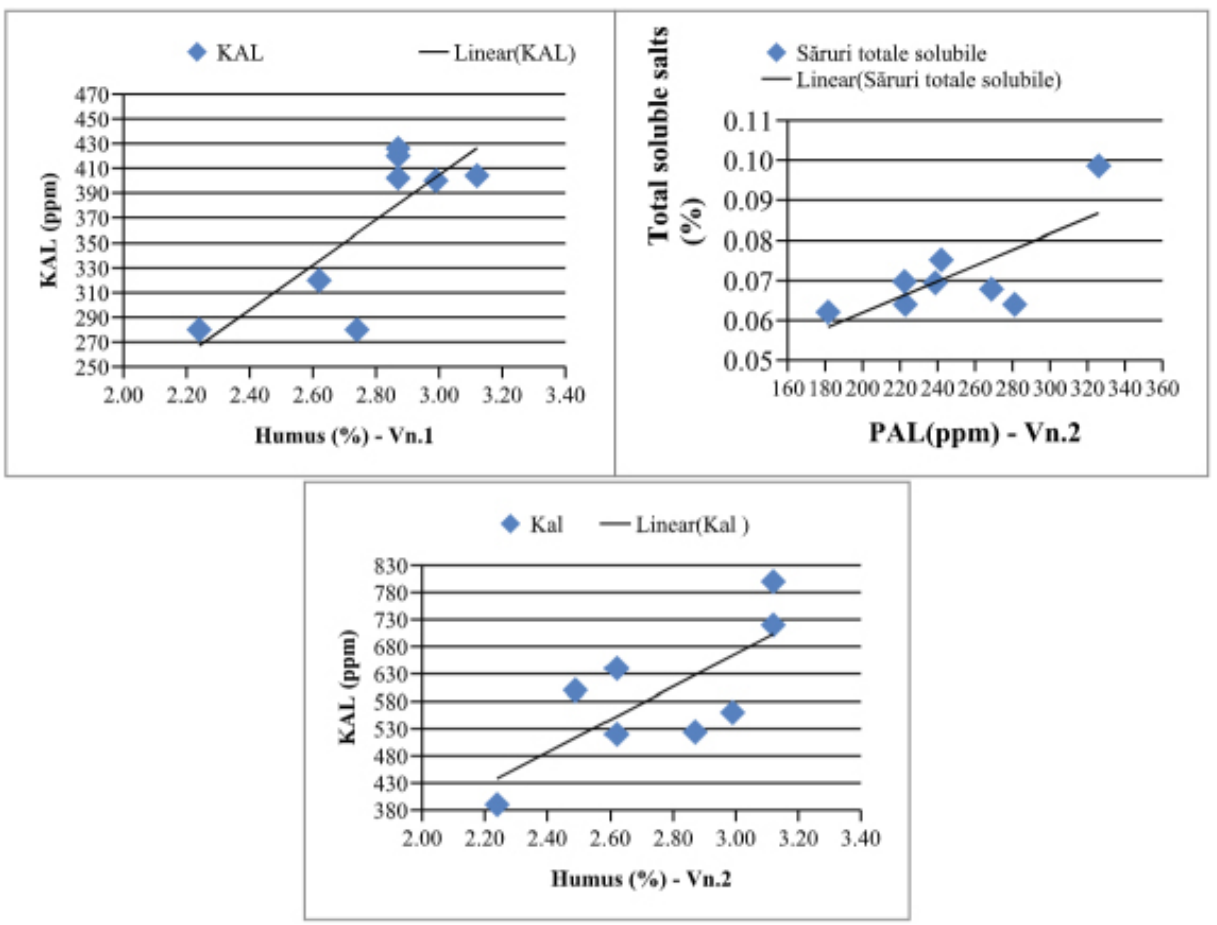

Figure 8. Correlations between agrochemical parameters under the influence of ameliorative plants and mulch variants

Soil agrochemical parameters correlations in 0-20 horizon

Under the influence of ameliorative plants, a positive correlation between soil total soluble salts and humus content was registered $(\mathrm{r}=0.72$, $\mathrm{p}<0.05$ ) (Fig. 7).

On the woodchips mulched rows (Vn.1), positive correlations between soil $\mathrm{K}_{\mathrm{AL}}$ and humus content were noticed $(\mathrm{r}=0.78, \mathrm{p}<0.05)$. On the wool mulched rows (Vn.2), positive correlations between soil total soluble salts with $\mathrm{P}_{\mathrm{AL}}(\mathrm{r}=0.73$, $\mathrm{p}<0.05$ ) and between $\mathrm{K}_{\mathrm{AL}}$ with humus content $(\mathrm{r}=0.75, \mathrm{p}<0.05)$ were observed (Fig. 8).

\section{Soil agrochemical parameters correlations} in 20-40 horizon

Under the influence of ameliorative plants, positive correlations between soil total soluble salts with $\mathrm{pH}(\mathrm{r}=0.71, \mathrm{p}<0.05)$, respectively with mineral nitrogen $(\mathrm{r}=0.75, \mathrm{p}<0.05) ; \mathrm{K}_{\mathrm{AL}}$ and humus content ( $r=0.85, p<0.05$ ) were observed (Fig. 9). 


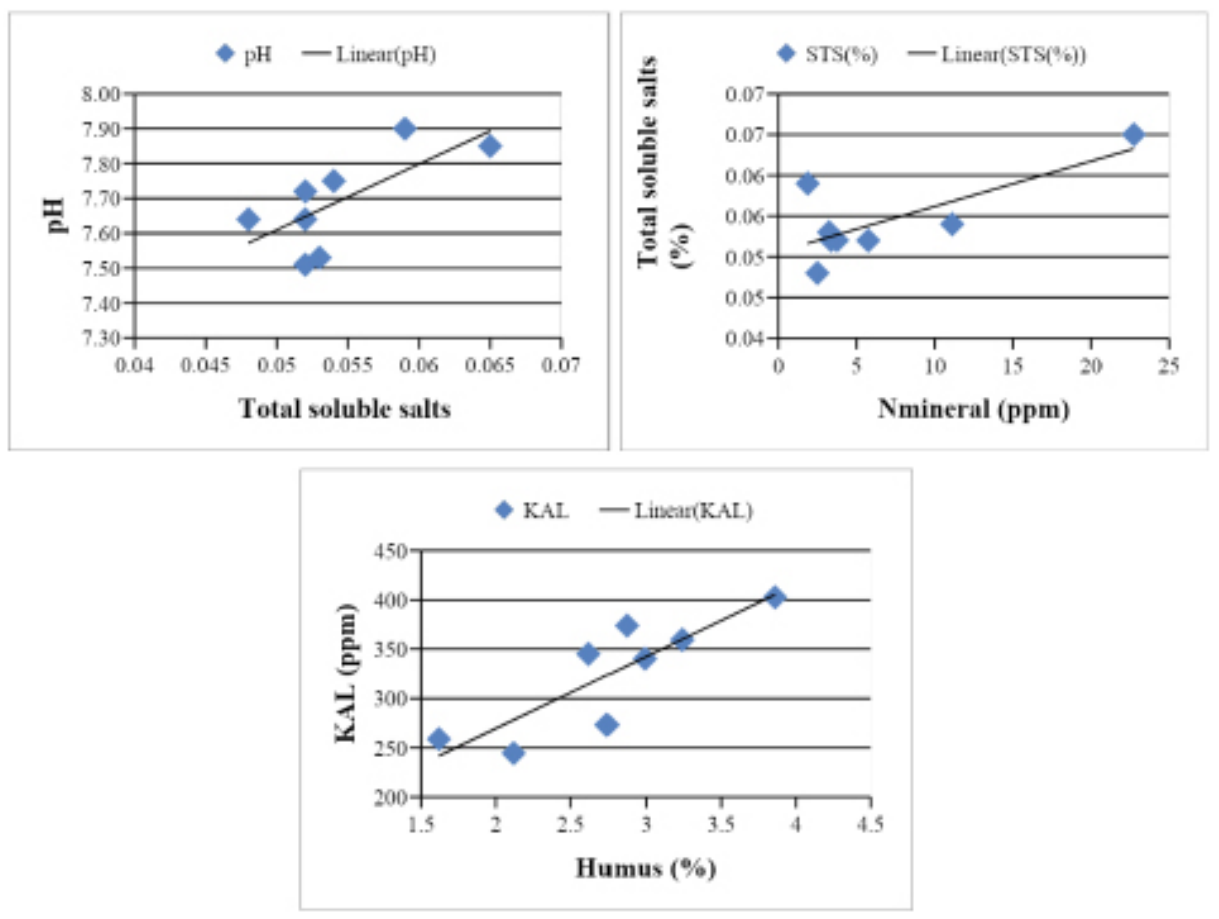

Figure 9. Correlations between soil agrochemical parameters in 20-40 horizon

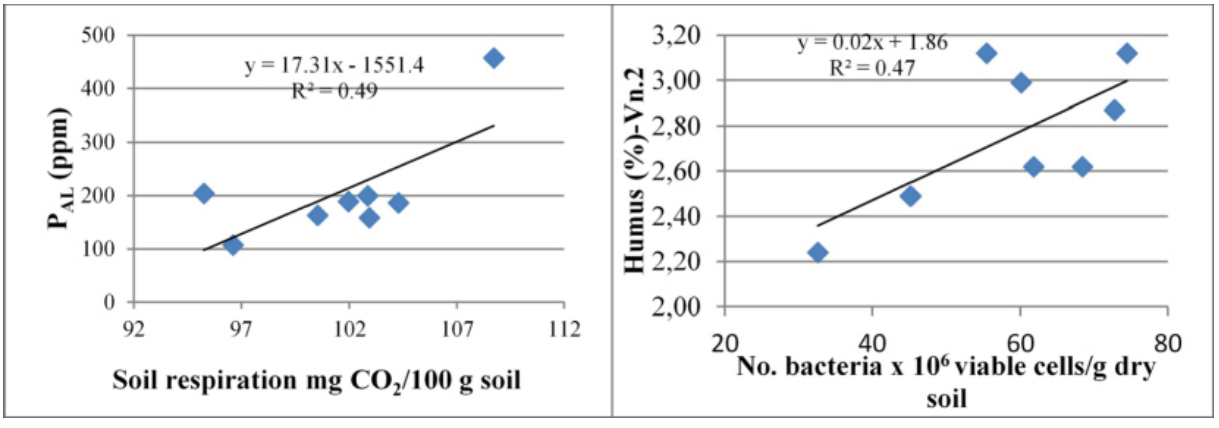

Figure 10. Correlations between microbiological and agrochemical parameters

Correlations between soil microbiological and agrochemical parameters

Analyzing the connections between microbiological and agrochemical parameters, under the influence of ameliorative plants, a positive correlation between soil respiration with $\mathrm{P}_{\mathrm{AL}}$ content $(\mathrm{r}=0.70, \mathrm{p}<0.05)$ was observed.

Under the influence of ameliorative plants combined with mulch variants, on the wool mulched rows a positive correlation between soil bacteria number and humus content was noticed $(r=0.69, \mathrm{p}<0.05$ ) (Fig. 10).

On the unmulched rows, correlations between soil bacteria number with humus content $(\mathrm{r}=0.68$, $\mathrm{p}<0.05)$, soil respiration with $\mathrm{K}_{\mathrm{AL}}$ content $(\mathrm{r}=0.83$, $\mathrm{p}<0.05$ ), soil respiration with humus content $(\mathrm{r}=0.69, \mathrm{p}<0.05)$ were calculated. A negative correlation between soil bacteria number with mineral nitrogen $(\mathrm{r}=-0.66, \mathrm{p}<0.05)$ was observed (Fig. 11).

Positive correlation between bacteria number and soil respiration with soil humus content on the wool mulched and unmulched rows confirmed their influences (Muller, 1965; Ștefanic et al., 2006; Madjar and Davidescu, 2009). Nitrogen is the most demanded nutrient by bacteria in residues decomposition (Burges and Raw, 1967), negative correlation between total number of bacteria and mineral nitrogen highlighted its consumption. Phosphorus and potassium are growth stimulants 


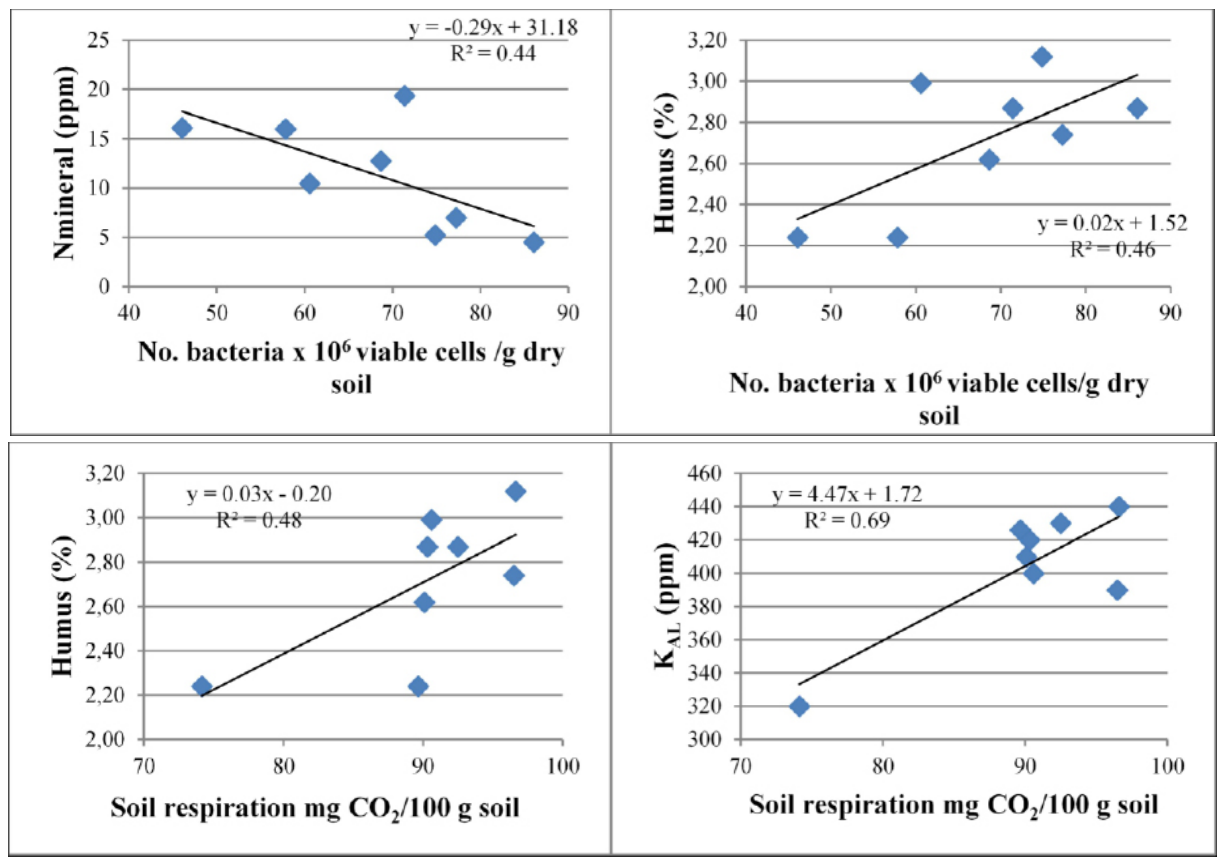

Figure 11. Correlations between microbiological and agrochemical parameters on the un-mulched rows

for soil microorganism (Muller, 1965; Ștefanic et al., 2006), positive correlation with soil respiration confirming this hypothesis.

\section{Conclusions}

The present study detailed the impact of using ameliorative plants (Sinapis alba L., Phacelia tanacetifolia L., Tagetes patula L.) and organic mulch (woodchips, wool) in improving the soil microbiological and agrochemical parameters, presenting in the same time the linear regression between soil quality indices. A strong significant correlation between the fungi number and soil respiration $(r=0.94, p<0.05)$ comparing with the control plot $(r=0.77, p<0.05)$ was registered on the mulched rows. One important positive correlation was confirmed between the soil bacteria number and humus content (correlation coefficient $r=0.68$ on the unmulched rows respectively $r=0.69$ on the wool mulched rows; $\mathrm{p}<0.05$ ). In the same time, the soil bacteria number increased consuming nitrogen $(r=-0.66, p<0.05)$. A significant positive correlation between soil respiration and assimilable potassium content $(\mathrm{r}=0.83, \mathrm{p}<0.05)$ was noticed, highlighting its role in growth of soil microorganisms.

\section{References}

1. Aghaalikhani M, Ehteshami SMR (2008). Biological profitability of maize inoculation with selected rhizosphere micro organisms (Pseudomonas fluorescens and Glomus intraradices) under Water Deficit Stress, archived at http://orgprints.org/view/projects/ conference.html.

2. Bettiol W, Ghini R, Galvão JAH, Ligo MAV, de Carvalho Mineiro JL (2002). Soil organisms in organic and conventional cropping systems, Scientia Agricola 59(3): 565-572.

3. Berca M (2011). Agrotehnică - transformarea moderna a agriculturii, Ed. Ceres, Bucharest.

4. Bergey DH, Holt JG (1994). Bergey's manual of determinative bacteriology 9. Wiliams and Wiliams Publishing House, Baltimore, USA.

5. Bjorkman M, Klingen I, Birch ANE, Bones AM, Bruce TJA, Johansen TJ, Meadow R, Molmann J, Seljasen R, Smart LE, Stewart D (2011). Phytochemicals of Brassicaceae in plant protection and human health - Influences of climate, environment and agronomic practice. Phytochemistry 72: 538-556.

6. Burges A, Raw F (1967). Soil biology. Academic Press, London and New York.

7. Butcaru AC, Stănică F, Matei GM, Matei S (2019). Influences of Soil Ameliorative Plant Species on the Organic Edible Rose Culture. ActaHorticulturae 1242: 107-114.

8. Butcaru AC, Stănică F (2018). Cultivation technology of organic roses for petal production. USAMVB Scientifique Papers, Series Horticulture, LXII: 203-210.

9. Butcaru AC, Stănică F, Madjar R (2017a). Influence of ameliorative plants and mulch on some soil agrochemical 
characteristics in an organic edible rose crop. USAMV Scientifique Papers, Series Horticulture, LXI: 101-106.

10. Butcaru AC, Stănică F, Matei GM, Matei S (2017b). Soil microbial activity in an organic edible rose crop, USAMV Scientifique Papers, Series Horticulture, LXI: 107-112.

11. de Araújo ASF, de Melo WJ (2010). Soil microbial biomass in organic farming system. Ciência Rural, 40 (11): 24192426.

12. deBaets S, Poesen J, Meersmans J, Serlet L (2011). Cover crops and their erosion-reducing effects during concentrated flow erosion. Catena 85: 237-244.

13. Dhima K, Vasilakoglou I, Garane V, Ritzoulis C, Lianopoulou V, Panou-Philotheou E (2010). Competitiveness and Essential Oil Phytotoxicity of Seven Annual Aromatic Plants. Weed Science 58: 457-465.

14. Domsch KH, Gams W (1970). Fungi in agricultural soils. T\&A Constable Ltd., Edinburg, London, 290.

15. Foucault Y, Lévęque T, Xiong T, Schreck E, Austruy A, Shahid M, Dumat C (2013). Green manure plants for remediation of soils polluted by metals and metalloids: Ecotoxicity and human bioavailability assessment. Chemosphere 93: 1430-1435.

16. Fuchs JG, Berner A, Mayer J, Smidt E, Schleiss K (2008) Influence of compost and digestates on plant growth and health: potentials and limits. Proceedings of the International Congress CODIS: 101-110.

17. Fuksa P, Hakl J, Brant V (2013). Energy balance of catch crops production. Zemdirbyste-Agriculture, 100(4): 355-362.

18. Grebenişan I (2007). Microbiologie - note de curs, Ed. Cartea Universitară, Bucharest.

19. Hooks CRR, Wang KH, Ploeg A, McSorley R (2010). Using marigold (Tagetes spp.) as a cover crop to protect crops from plant-parasitic nematodes. Applied Soil Ecology 46: 307-320.

20. Hossain S, Bergkvist G, Glinwood R, Berglund K, Mårtensson A, Hallin S, Persson P (2015). Brassicaceae cover crops reduce Aphanomyces pea root rot without suppressing genetic potential of microbial nitrogen cycling. Plant Soil, 392:227-238.

21. ITAB (Institut technique de L'Agriculture Biologique) and GRAB (Groupe de Recherche en Agriculture Biologique) (2005). Guide technique, Produire des fruits en agriculture biologique, France.

22. Lia A, Lia S, Lia HB, Xua DP, Xub XR, Chenc F (2014). Total phenolic contents and antioxidant capacities of 51 edible and wild flowers. Journal of functional foods 6: $319-330$.

23. Liu J, Khalaf R, Ulén B, Bergkvist G (2013). Potential phosphorus release from catch crop shoots and roots after freezing-thawing. Plant Soil 371: 543-557.

24. Lipşa FD, Ulea E, Irimia N, Talpan IV (2008). Cercetări privind influenţa fertilizării şi al amestecurilor complexe din structura covorului vegetal al unor pajiști temporare asupra microflorei solului. Scientifice Papers, Agronomy series, USAMV Iași, 51: 140-147.
25. Madjar R, Davidescu V (2004). Retention and Migration Process of Potassium in an Organic Substrate for Horticulture. Acta Horticulture 633: 309-314.

26. Madjar R, Davidescu V (2009). Agrochimie, USAMV București.

27. Maltais-Landry G (2015). Legumes have a greater effect on rhizosphere properties $\mathrm{pH}$, organic acids and enzyme activity) but a smaller impact on soil P compared to other cover crops. Plant Soil 394: 139-154.

28. Muller G (1965). Biologia solului (Soil biology). Agro Silvică Publishing House, Bucharest.

29. Neață G (2002). Agrochimia și Biologia solului. Printech Publishing House, Bucharest.

30. Norvell AWA, Bjorkman T. and Harman G. E. (1999). Solubilization of Phosphates and Micronutrients by the Plant-Growth-Promoting and Biocontrol Fungus Trichoderma harzianum Rifai 1295-22. Applied and Environmental Microbiology, 65(7): 2926-2933.

31. Pacwa-Płociniczak M, Płaza GA, Poliwoda A, PiotrowskaSeget Z (2013). Characterization of hydrocarbondegrading and biosurfactant-producing Pseudomonas $s p$. P-1 strain as a potential tool for bioremediation of petroleum-contaminated soil. Environment Science Pollution Resources 21: 9385-9395.

32. Ramirez RA, Henderson DR, Riga E, Lacey LA, Snyder WE (2009). Harmful effects of mustard bio-fumigants on entomopathogenic nematodes. Biological Control 48: 147-154.

33. Robacer M, Canali S, Kristensen Lakkenborg H, Bavec F, Mlakar Grobelnik S, Jakop M, Bavec M (2016). Cover crops in organic field vegetable production. Science Horticulturae 208: 104-110.

34. Santos PC, Santos VHM, Mecina GF, Andrade AR, Fegueiredo PA, Moraes VMO, Silva LP, Silva RMG (2015). Phytotoxicity of Tagetes erecta L. and Tagetes patula L. on plant germination and growth. South African Journal of Botany, 100: 114-121.

35. Stănică F, Peticilă GA (2011). Înființarea plantaţiilor pomicole. Valahia University Press, Dâmbovița.

36. Ștefanic G, Săndoiu DI, Gheorghiță N (2006). Biologia solurilor agricole. Elisavaros Publishing house, Bucharest.

37. Velivelli SLS, Sessitsch A, Prestwich BD (2015). The Role of Microbial Inoculants in Integrated Crop Management Systems. Potato Research 57: 291-309.

38. Vinokur Y, Rodov V, Reznick N, Rot I, Goldman G, Horev B, Umiel N, Friedman H (2006). Rose petal tea as an antioxidant-rich beverage: cultivar variability. Journal Food Science, 71: S42-S47.

39. Wang D, Rosen C, Kinkel L, Cao A, Tharayil N, Gerik J (2009). Production of methyl sulfide and dimethyl disulfide from soil-incorporated plant materials and implications for controlling soilborne pathogens. Plant Soil 324: 185-197.

40. Wang X, Gub M, Niuc G, Baumann PA (2015). Herbicidal activity of mustard seed meal (Sinapis alba 'Ida Gold' and 'Pacific Gold') on weed emergence. Industrial Crops and Products 77: 1004-1013. 